\title{
EFFECT OF TAX SYSTEM ON THE ECONOMIC DEVELOPMENT OF A NATION: NIGERIA EXPERIENCE
}

\author{
Akinrinola, Olalekan Oladipo ${ }^{1 *}$, Oreoluwa, Bamidele ${ }^{2}$ \\ ${ }^{1,2}$ Department of Accounting, Finance \& Taxation Caleb University, Imota, Lagos Nigeria
}

\section{*Corresponding Author: -}

\begin{abstract}
: -
The economic development of Nigeria has been trembling over the years, even when the country has been acclaimed the biggest economy in Africa since 2014. This is in contrast to other developing countries and subSaharan countries that have up-scaled and accelerated their economic development in contemporary times. Such nations have utilised tax revenue to galvanise their economic development, but Nigeria does not have much to show for this. The country records one of the lowest percentage of tax revenue to GDP of about $6 \%$ compared to an average of $17 \%$ for sub-Saharan African countries and about $30 \%$ for OECD countries. This study examined the effect of the tax system on the economic development of the nation, using the human development index as the parameter for measuring economic development while assessing the tax system by the tax to GDP ratio. A qualitative research method was adopted by reviewing empirical studies and analysing secondary data gathered from relevant sources. From the reviews, discussions and analysis, there abounds compelling data to show that there is significant positive relationship between the tax system and the economic development of a nation. However, in the case of Nigeria, there appears to be uncoordinated and ineffective tax system that has inadequately impacted on her economic development. Taking a lead from other developing countries like Rwanda, recommendations were made for restructuring and synergising the tax system while utilizing information technology and ensuring accountability and transparency.
\end{abstract}

Keywords: - Economic development, Tax system, Human development index, Tax to gap ratio, Tax revenue.

\section{(a) $(\$)$}




\subsection{INTRODUCTION}

Many nations of the world are at different stages in their national development strides. While some are classified as developed, some are termed developing while others are simply referred to as underdeveloped. One of the major drivers of this quest for national development is economic growth and development. According to Denver-South, (2018) Economic development is the composite or universal set of the developmental process of the entire economy of a nation, comprising not only the economic growth, but the creation, improvement and sustainability of the economic, political, and social well-being of the nation via the instrumentality of innovation, skills and infrastructure. Underlying this phenomenon is the Neo-classical economic growth theory, which posits that the accumulation of capital within an economy and how the capital is used significantly impacts economic growth, (Solow \& Swan, 1956). Another theory underpinning national economic development is the endogenous growth theory. This is a development on the growth theory and focuses on the internal forces that accentuate growth and development (Aghion \& Howitt, 1998).

From existing studies, one of the major indices identified as indicator of national economic development is Human Capital Development Index, (HDI), (Mazek, 2015; Sharhoodi, 2010). In 2013, Nigeria was acclaimed the biggest economy in Africa with a nominal GDP of \$510b, thereby making her the 20th largest economy in the world by nominal GDP, (Brookings, 2015; World Bank, 2014). Unfortunately, this economic feat has not translated into a corresponding economic development of the country. The real GDP per Capital for the country is an abysmal \$2,230, which is rated as one of the lowest (138th. out of 186 countries) in the world. Similarly the Human Development Index (HDI) for Nigeria is 0.53 (in value) and rated 158th out of 180 countries in the world (World Bank, 2019). This shows clearly that Nigeria has been lagging behind other developing and contemporary African countries. In the quest for promoting national economic growth and development, tax revenue serves as a veritable and sustainable source of income for different nations across the globe. It is on record that some of the European countries, (e.g. Denmark and Finland) attribute as high as $40 \%$ of their Nominal GDP to revenue from taxation, while across the Sub-Saharan African countries the average Tax to GDP ratio was about $17 \%$. Ironically, Nigeria's Tax to GDP has been crawling at an average of 5 to $6 \%$ over the years, (World Bank, 2019; OECD, 2020).

Hitherto, the natural resources used in generating revenue have been dwindling across the globe. Nations have had to turn to and rely on tax revenue, (which has proved to be much more sustainable), to accentuate their economic development. Nigeria has recorded an abysmally low level of economic growth and development over the years compared to some of the developing and contemporary Sub-Saharan Africa nations. Despite the various innovations employed by the Nigerian government and various incentives to taxpayers, there is yet no significant improvement in the efficiency of the entire tax system to stimulate the revenue generation for economic development. This is reflected in the various indices used in measuring economic development. This problem of perceived inefficiency in tax system gave rise to questions bothering on the administration of the tax system.

The primary aim of this study is to examine the impact of efficient tax system on economic development of Nigeria by examining the parameter for assessment of tax system, tax to GDP ratio and establish the correlation with the HDI as a measure of the economic development. This study is therefore predicated on this background, to review the tax system as a whole and see how a holistic engagement of the entire tax system can significantly impact upon the economic development of the country. One of the major identified variables for assessing the tax system is the tax to GDP ratio. This study examined the tax to GDP trend as a parameter for assessing the tax system, tax revenue and the impact on the HDI of the nation for measuring economic development. A qualitative research methodology will by employed by utilizing desk review of empirical studies as well as review and analysis of secondary data gathered.

\subsection{Statement of Research Hypothesis}

The specific objective of the study is to ascertain the effect of the Nigerian tax system on her economic development. The study will be guided by this hypothesis that, there is no significant relationship between the tax system and economic development of Nigeria.

$\mathrm{H}_{0} 1$ : Tax system has no significant impact on human capital development in Nigeria.

$\mathrm{H}_{1}$ 1: Tax system has significant impact on human capital development in Nigeria.

\subsection{Scope and significance of the Study}

While there are various indices that can be used to measure the development of a nation's economy, this study measured economic development using the Human Development Index (HDI). To assess the tax system, the major parameter identified is the Tax to GDP ratio. To achieve this, a study for 10 years covering the period 2010 to 2019 was carried out utilizing secondary data from Federal Inland Revenue Services (FIRS), Nigeria Bureau of Statistics (NBS), Central Bank of Nigeria, other international institutions like World Bank, International Monetary Fund (IMF) and relevant economic journals. The study will enhance efficiency of the tax administration system. Also, it will aid the relevant government institutions and legislators in formulating policies and legislating tax laws that will lead to a significant improvement in the tax revenue collections and ultimately promoting economic development of the nation.

\subsection{Conceptual Review}

\section{The concept of tax and taxation}

Tax is a compulsory charge levied on the citizens, (or non-citizens), on their property, income or transactions carried on in the state or nation by the government for the purpose of providing infrastructures for economic growth and development. According to Nzotta (2007), tax is a compulsory contribution levied on the citizens or non-citizens by the government as a result of taking up residence in the state, doing business and generating income, or on the property of the citizens. 
Consequently, there is an obligation on the citizens (or non-citizens) to pay taxes and not to evade them. Also, being a levy imposed strictly at the discretion of the government, it implies that the benefit, from the government, directly attributable to the taxes may not be established by the taxpayer. Tosin \& Abizadeh (2005) identified impacts taxes have on economic development of a nation via the formulation of fiscal policies, namely:

Rate of investment in the economy can be influenced by taxes like Income tax, Company Income tax and Capital Gains Tax. The supply of labour growth could be slowed down in favour of leisure choice. Tax policies could discourage the impact of research and development. Economic sectors with low productivity will attract a flow of resources through the impact of tax. Human capital can be distorted by the impact of high taxes. Taxes are broadly divided into Direct and Indirect taxes. Examples of direct tax include personal income tax, company income tax, and petroleum profit tax. Indirect tax includes value added tax, excise duty, custom duty. In Nigeria, the constitution defines the different categories of taxes and the arm of government responsible for each category of tax.

\section{The Nigerian tax system}

Tax System can be defined as the composite parts involved in the tax processes, from the legislature of the tax laws or issuance of the tax policies, to the administration of the levy, collection, monitoring and enforcement and up to compliance for payment by the tax payers. Ogbonna and Ebimobowei (2011) asserted that the tax system therefore consists of: tax policy, tax laws, tax administration and tax payers. The fiscal operations in Nigeria is structured into three tiers, the Federal, State and Local governments with each tier of government having control over separate tax jurisdiction.

Tax Legislation entails the enacting of laws on taxation, levies and rules guiding tax administration process. It also include the review, modification and amendments of existing tax laws in keeping with current trends, best global practices and realities of the local and national economy. Each of the tax laws is embedded with provisions specifying the tax authorities responsible for the administration of the requisite taxes. The Finance Act 2020 contains amendments on some of the existing tax laws like Companies Income Tax Act, Personal Income Tax Act, Value Added Tax Act, and Petroleum Profit Tax Act, (PPTA). The Petroleum Industry Bill, (PIB) is still before the National Assemble awaiting passage into law. This will eventually replace the PPTA.

Tax Policy is the framework by which a government determines what taxes to levy, in what amounts, and on whom. This establishes a sustainable system that would ensure reliable sources of revenue to government and support the economic growth and development of the nation, (FIRS, 2017). The national tax policy (NTP) was revised and approved in February, 2017. It provides a guideline for the administration of the tax laws in the country. Some of the outlines of the revised NTP include the principles for administration and collection of taxes; the rules and guidelines for taxation administrators and stakeholders; a provision on basis for establishing an efficient and effective tax system.

Tax Administration or revenue service is a government agency responsible for collection of all tax revenues due in a fair and efficient way with limited costs for taxpayers and the tax administration itself. Tax authorities are divided into three, representing the three arms of government. We have the Federal Inland Revenue Services representing the Federal government; State boards of internal revenue services representing the State government; and the Local government revenue committees for each of the 774 local government authorities. FIRS is responsible for the collection of corporate taxes; State boards of Internal revenue is responsible for collection of personal income taxes, while the Joint Tax Board, JTB acts in a coordinating capacity for all the state revenue boards. The Local government revenue committee is responsible for collection of levies and rates at the local government levels. The different Tax authorities operate within the designated powers and scope. Consequently, the tax authorities execute the administration of the tax processes and ensure compliance to the relevant tax laws within their respective jurisdiction. Usually, a tax identification number, TIN is allocated to each tax payer and is unique to such tax payer.

\section{Economic development and tax contribution}

Economic development is a composite of human welfare development, education, health, employment as well as overall economic growth. Economic growth is a quantitative measure of the increases in goods and services or income. Gross national income (GNI) or gross domestic product (GDP) are usually used to measure economic growth. However, according to Agarwal (2019), economic development is a broader concept which involved sustainability towards meeting the present needs of the populace without compromising future needs. Economic growth is a sub-set and integral part of economic development. In addition to economic growth, it also encompasses social, educational, healthy living and progress in general well-being of a nation. While Growth is a vital and requisite condition for economic development, it does not a necessarily guarantee development.

One of the major parameters identified by Macek (2015), for measuring economic development is the Human Development Index. This is a measure of the human capital development for a nation. The Human Development Index (HDI) is an index that measures key areas of human development. The HDI is a composite of three dimensions which are: life expectancy, which relates to a long and healthy life; expected years of schooling of children at school (including entry age and mean years of schooling of the adult population), which relates to access to education; and Gross National Income per capita (adjusted for price level changes of the country), which relates to decent standard of living.

\subsection{Theoretical framework.}

The underlying theories for the study are the Endogenous growth theory and Neo-Classical economic growth theory. 


\section{Neo - classic Theory}

The foundation of the neoclassical theory was laid by Adam Smith and David Ricardo. The theory was later developed by Alfred Marshall and Vilfredo Pareto. However, Robert Solow and Trevor Swan were the first to introduce the neoclassical growth theory as an economic model of long-run economic growth under the neoclassical economics framework in 1956. It expounded long-run economic growth by x-raying capital accumulation, labour or population growth, and increases in productivity. The basic postulations are outlined below:

i. Economic growth is a function of three factors, namely labour, capital, and technology.

ii. Technology portends immense contributions to economic growth while resources from capital and labour are limited. iii. The accumulation and usage of capital within an economy is instrumental to economic growth. (Solow \& Swan, 1956)

\section{Endogenous Growth Theory}

The endogenous theory was developed by Paul Romer, an American economist in 1986 as an alternative to the neoclassical growth theory. The theory queried the existence of gaps in wealth among underdeveloped and developed countries could persist if investment in physical capital like infrastructure is subject to diminishing returns. The theory upholds that economic growth is predominantly the consequence of internal forces as opposed to the external forces. The basic assumptions of endogenous theory according to Paul Romer are:

i. Internal factors like human capital, innovation, and investment capital, rather than external, uncontrollable factors are propellers of a steady growth of prosperity

ii. The countries acclaimed as "developing" need to engage in a continuous process of economic development in order to experience sustainable prosperity.

iii. Sustained economic growth is a process of continual transformation.

iv. Economies that cease to transform themselves are destined to fall off the path of economic growth. (Corporate Finance Institute, 2019).

\subsection{Empirical review}

From the review of existing studies on the research topic, there appears to be a consensus on findings that there is a positive relationship between tax revenue and the economic development of the state. Some of the studies also focus on the dynamics of the tax revenue system and the degree of their respective or overall impacts on the economic development of the nation. An empirical review of the studies is enunciated here.

Ogbonna and Appah (2016) while reviewing the findings of the expert groups of United Nations (2000) pointed out that tax revenue contributes immensely to economic development, consequently there is need to reorganise the tax system of a country in order to realize the ideal tax revenue that will arise from fair and equitable share of tax burden. The emphasis of their work was on the need to streamline the tax nation's tax system in order to achieve optimal revenue generation. However, it must me noted that a faulty tax system could still generate some tax revenue, albeit to a sub-optimal level. Ogbonna and Ebimobowei (2012) used relevant descriptive statistics and econometric analysis to examine the impact of tax reforms and economic development of Nigeria. The findings showed that there is a positive and significant relationship between tax reforms and tax revenue capacity of the nation which ultimately enhances the provision of basic infrastructure and improvement of the social wellbeing of the populace, thereby leading to economic development. Thus, there is need for continuous reforms of the tax system.

Ofoegbu, Akwu and Oliver (2016), in their study on the effect of tax revenue on economic development of Nigeria concluded with some findings among which is that there is a positive and significant correlation between tax revenue and economic development. The study concluded on this finding through the use of tenyear annual time series data for 2005 to 2014. The data was used to estimate a linear model of tax revenue and human development index using ordinary least square (OLS) regression method.

Similarly, Ibanichuka, Ikebujo and Akani (2016) in the examination of the effect of tax revenue on economic development of Nigeria 1995-2014 analysed the time series data using multiple regression analysis. Findings showed that there is positive relationship between revenues collected by the government at the federal level through company income tax (CIT), value added tax (VAT) and customs and excise duty (CED), and the human development index (HDI) of the nation. Eyi, (2014) posited that the Nigerian tax system has no significant impact on economic development due to several challenges confronting the system. The author opined that the Nigerian tax system should be reformed to orchestrate a system that would have a significant impact on economic development. This will engender an effective tax system, thereby improving the internally generated revenue in the country. Adudu and Ojeneye (2015) submitted that efficient tax reforms are requisite condition for sustainable economic development while advocating for a holistic review and enhancement of the tax administration machinery. Abata (2014) observed that the tax administration system has a significant impact on revenue generation in Nigeria. The study opined that tax evasion and lack of training of tax officers portends an adverse effect on generation of government revenue in Nigeria. Sharhoodi (2010), while investigating the factors that affect the efficiency of tax system, observed that certain salient factors are effective in the efficiency of the tax system, and concluded that tax laws, fines and formal procedures are not effective in achieving an efficient tax system. In contrast, the use of information technology - IT was an effective factors in improving the tax system, tax promotions, training of tax personnel and taxpayers.

Okwara and Amori (2017) however submitted that government need to state clearly the objectives of the tax system and how these objectives relates to each other. This, according to the study, will enable the tax administration have a focus to give proper education to taxpayers on the reason to pay taxes as and when due. Pantamee and Mansour (2016) advocated a modern tax administration model made up of four components, namely: input, output, transformation process and 
outcome. They concluded that in order for the tax administration to generate adequate revenue, the different components are expected to work in an integrated approach.

Most of the studies reviewed appear to recommend a generalised view on improving the tax system without giving clear directions. This gap was addressed by Okwara \& Amori (2017) who recommended that governments should rather set clear objectives for its tax system and also specify the relationships between the components of the objectives. A further development on this view was submitted by Pantamee and Mansour, (2016) who advocated that to generate optimal revenue, the tax system must work in an integrated approach, incorporating all the components defined for its objectives. However, part of the limitation of Pantamee \& Mansour's study is that the Morden congruence model advocated has not been tested.

Ewa, Adesola and Essien, (2020) submitted in their findings that taxation is still a solid socio-political and economic tool necessary for economic development. However, tax leakages arising from tax evasion, avoidance and low tax base made the Nigeria experience worsen, adverse and contrary to expectations. The study observed that why tax leakages are major concern across the countries of the world globe, the situation in Nigeria is cancerous due to corruption, lack of transparency and existence of bad leadership and governance

The study however recommended that management and utilization of tax resources should be driven by transparency on the part of government as this will gives the taxpayers a greater assurance of the collection and application of taxes. The study also recommended improvement of the Nigeria's tax administrative management efficiency through blockage of identified and potential leakages in the collection of tax revenue. In addition, the study recommended that the country's tax base should be expanded to attract more tax revenue.

\subsection{Methodology}

The methodology adopted is the qualitative research method utilising a desk review analysis approach based on secondary data from journal, reports and publications from World BANK, OECD, UNDP, FIRS, CBN and Nigeria Bureau of Statistics. The focus of the analyses is a review of studies and analysis of data on the identified parameter for assessing the tax system, which is the tax to GDP ratio as well as indices for assessing the nation's economic development, which is HDI. Analyses of these two parameters were made based on comparison the trend of Nigeria's performance and a comparison with Sub-Saharan African countries, OECD countries average and the world average performance data.

\subsection{Discussion}

\subsection{Tax-to-GDP ratio over time}

Governments across the globe, and indeed in Africa, have realised that the primary step towards optimizing revenue collections drive is to enhance the efficiency of the tax system. Sub-saharan Afican, (SSA) countries having witnessed drastic declines in economic development as occasioned by weak macroeconomic performances have resulted to discovery and utilization of alternative sources of income aside the traditional sources of natural and wasting resources. Taking a cue from developing and developed countries across the globe, a number of SSA have embarked on reformation of tax laws and processes, having realised that tax is a more sustainable source of revenue and a catalyst for economic development, thus providing the required funds for infrastructure and thereby engender economic development. Invariably, the level of compliance and execution of the different tax reform initiatives is slow, particularly in a country like Nigeria; with a crawling tax to GDP ratio of $6 \%$. A little jump in the drive will have such a conflagrating effect on the economies of the nation. Data abounds about immense opportunities in the SSA countries which are largely untapped and unharnessed, which would serve as a veritable tool for driving tax revenue generation, (Yusuf, K., 2017).

Maiye and Isiadinso, (2019) observed that the rate of growth of tax revenue is what determines the rate of growth of the tax to GDP ratio. Consequently, the tax to GDP ratio is a reflection of the level of economic activity within a country; in other words, GDP growth should be positively correlated to tax revenue. However, the incidence of low tax to GDP ratio is characteristic of developing nations, particularly Nigeria. Prior to the global recession in 2016 and 2018, Nigeria was acclaimed the largest economy in Africa by nominal GDP, after the re-basement of the GDP that was done in 2014. The impact of this feat has not been shown in the tax to GDP ratio, neither in all the other vital economic development indices. Notwithstanding the reported growth, the taxto-GDP ratio has remained at $6 \%$ which is even relatively lower when compared to other developing economies. Some of the factors Maiye and Isiadinso attributed to this abysmal level of tax to GDP in Nigeria include: narrow tax base, unorganized informal sector, government tax incentive and exemption framework,

Examples of an African and European countries that carried out a holistic tax reforms and have been able to increase their tax revenue and corresponding ratios to GDP are Rwanda and Georgia

Georgia was one of the countries that emerged from the collapse of the former Soviet Union. Thereafter, Georgia was confronted with the quest for economic development. As at 2003, the government faced several economic challenges ranging from corruption, to tax evasion fraud and illegal tax credits being perpetrated by tax and government officials. However, through the initiation of diverse reforms and restructuring, Georgia was able to surmount the numerous challenges. In order to improve her economic developments, the country carried out reforms of the tax system to enhance the efficiency of the tax system, thereby increasing her tax to GDP ratio from $9 \%$ in 2003 to $23.8 \%$ by 2008 , and currently at 25.7 as at 2020 . Some of the measures introduced to revamp the tax system include establishing a simplified tax code, reducing the tax rates and eliminating multiple local taxes thereby gaining a broader tax base. In addition, technology was introduced to facilitate electronic tax filing system which greatly enhanced the ease of paying taxes, engendered greater compliance and enforcement, while drastically reducing the incidence of corruption. 
Rwanda, emerging from the civil war and genocide of 1994, initiated diverse reforms to rebuild the nation and economy. By 2003 the Rwanda Revenue Authority (RRA) established the electronic Tax Information System for integration of the tax processes. Between 2005 and 2013, the RRA strengthened the tax administration processes by engaging in education of taxpayers coupled with diverse tax reforms to enhance the efficiency of the tax system. Also, a feedback mechanism was established through a call centre created to respond to queries from tax payers. Consequently, the tax to GDP ratio increased from $9.6 \%$ in 2000 to $13.4 \%$ in 2013 and 17.15 by 2018 . This leap in tax revenue collections was realised through improvement of the tax administration, tax reforms and new legislations, greater compliance and the broadening of the tax base.

The OECD, (2020) in her report on "Revenue Statistics in Africa 2020" reviewed the performances of selected 30 major African countries as regards their tax to GDP contributions for the period 2010 to 2018. The report observed that since 2010, the average tax-to-GDP ratio for the 30 African countries has increased from $15.1 \%$ in 2010 to $16.5 \%$ in 2018 , indicating a $1.4 \%$ point jump. For the same period, the tax-to-GDP ratio in Nigeria has decreased from $7.3 \%$ to $6.3 \%$, a $1 \%$ point dip. Over the last decade, the highest tax-to-GDP ratio recorded by the country was $9.6 \%$ in 2011 , while recording the lowest rate of $5.3 \%$ in 2016. Nigeria's tax-to-GDP ratio in $2018(6.3 \%)$ was lower than that of the average of the 30 African countries reviewed $(16.5 \%)$ by a16.7 percentage points and also lower than the average tax to GDP ratio for Latin America and the Caribbean (23.1\%), (OECD, 2020).

Table 1 - Human Development Index (HDI) \& Tax to GDP ranking of selected countries

\begin{tabular}{|l|l|l|}
\hline COUNTRIES & HDI (RANKING) & TAX TO GDP RATIO \\
\hline NIGERIA & & \\
\hline SOUTH AFRICA & 161 & 6.1 \\
\hline GABON & 114 & 26.5 \\
\hline GHANA & 119 & 11.5 \\
\hline ALGERIA & 138 & 12.6 \\
\hline MEXICO & 91 & 26.6 \\
\hline NORWAY & 74 & 16.5 \\
\hline BELGIUM & 1 & 39.9 \\
\hline SWEEDEN & 14 & 42.9 \\
\hline KENYA & 7 & 42.9 \\
\hline
\end{tabular}

Source: Author's compilation from 2020 Human Development Index (HDI) Ranking and World Bank Report, (2021).

From Table 1, it is apparent that Nigeria's tax to GDP ratio ranks amongst the lowest in the world, either compared with contemporary sub-Saharan African countries like Ghana, Kenya or Gabon, or other developed countries like Norway, Sweden or Belgium. A parallel could also be drawn from the positive correlation of the nation's tax to GDP ratio and HDI ranking. A country like Norway ranked as number 1 on the HDI index records a tax to GDP ratio of 39.9\%, while Nigeria with a ratio of $6 \%$ is ranked 161 out of 189 countries.

\subsection{HDI value and rank - Nigeria's standing}

The HDI value of Nigeria increased between 2005 and 2019 from 0.465 to 0.539 , the increased 2019 value of 0.539 was not in any way impressing compared with other nations. With that value of 0.539 in 2019 , the country still fall into the category of countries with low human development with ranking of 161 out of 189 ranked countries and territories as shown in Table 1.

A progress review of Nigeria's status of the HDI indicators between 1990 and 2019, as shown in Table 2 revealed that life expectancy at birth increased by 8.8 years, from 45.9 in 1990 to 54.7 in 2019 while expected years of schooling increased by 3.3 years, from 6.7 in 1990 to 10.0 in 2019 . The GNI per capital increased by about 58 percent from 3,109 to 4,910 measured in purchasing power parity denominated in United State dollar (PPP \$)

Table 2 - Nigeria Human Development Index (HDI) Indices from 1990 to 2019

\begin{tabular}{|l|l|l|l|l|l|}
\hline $\begin{array}{l}\text { Index } \\
\text { Year }\end{array}$ & $\begin{array}{l}\text { Life expectancy at } \\
\text { birth }\end{array}$ & $\begin{array}{l}\text { Expected years } \\
\text { of schooling }\end{array}$ & $\begin{array}{l}\text { Mean years of } \\
\text { schooling } \\
(2017 \text { PPP \$) }\end{array}$ & HDI value \\
\hline 1990 & 45.9 & 6.7 & n/a & 3,109 & n/a \\
\hline 1995 & 45.9 & 7.2 & n/a & 2,776 & n/a \\
\hline 2000 & 46.3 & 8 & n/a & 2,739 & n/a \\
\hline 2005 & 48.3 & 9 & 5.2 & 3,675 & 0.465 \\
\hline 2010 & 50.9 & 8.4 & 5.2 & 4,636 & 0.482 \\
\hline 2015 & 53.1 & 9.7 & 6.2 & 5,356 & 0.526 \\
\hline 2016 & 53.5 & 9.5 & 6.3 & 5,160 & 0.526 \\
\hline 2017 & 54 & 9.7 & 6.4 & 5,032 & 0.531 \\
\hline 2018 & 54.3 & 9.7 & 6.5 & 4,929 & 0.534 \\
\hline 2019 & 54.7 & 10 & 6.7 & 4,910 & 0.539 \\
\hline
\end{tabular}

Source: Author's compilation from 2020 Human Development Index (HDI) Ranking and World Bank Report, (2021). 
In 2014, Nigeria was acclaimed the biggest economy in Africa with a nominal GDP of \$510b, and a Cumulative Average Growth Rate (CAGR) of $5.3 \%$ by 2020 , thereby making her the 20th largest economy in the world by nominal GDP, (Brookings, 2015; World Bank, 2014). Unfortunately, this economic feat has not translated into a corresponding economic development of the country. Despite strong economic growth at a Cumulative CAGR of 5.3\% post-rebasing, this has not translated into corresponding economic development as revealed by the various parameters for measuring economic development. Nigeria has witnessed economic growth without it translating to growth in rate of employment in the country. The palsy average growth rate of $1.3 \%$ of the employment growth reveals the persistent incidence of high poverty and unemployment, giving way to a steady increase in the rate of unemployment and underemployment. As at 2011, the official unemployment rate was $6.0 \%$, rising to $8.2 \%$ in 2015 , while the underemployment rate of the labour force stood at $18.3 \%$. The "pseudo" growth in the Nigerian economy appears to be attributable to the services and agriculture sectors of the economy. However, limited income opportunity and low productivity levels have only resulted in abject poverty and miserably low standard of living for the burgeoning population in Nigeria. Consequently, these have exacerbated the need for pragmatic and sustainable economic development initiative that transcends the GDP factor, (PWC, 2020).

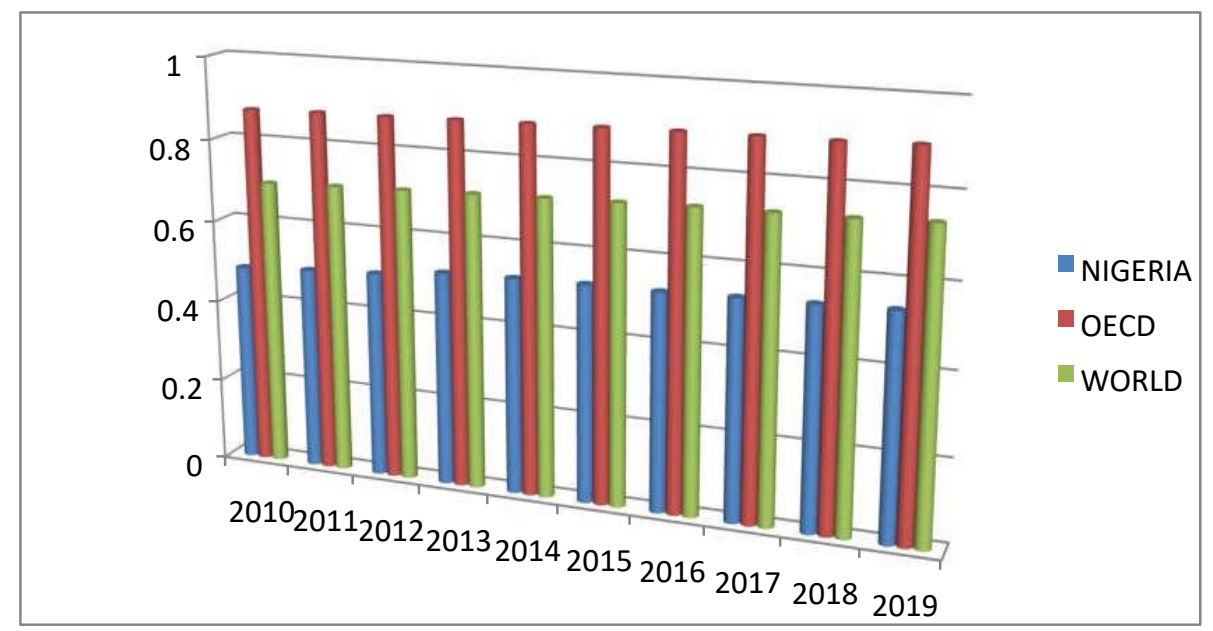

Figure 1: HDI (Values) For Nigeria, OECD and World (Average) - 2010 to 2019. Compiled from: World Bank Report, 2020.

At a HDI value of 0.51 , Nigeria is classified as a "low human development" country, with a rank of 152 amongst 188 countries. Between 2005 and 2014 however, Nigeria's HDI value improved only marginally from 0.467 to 0.514 . Of the 27 countries classified as "low human development" (out of the total 188 ranked countries), Nigeria with HDI of 0.51 ranked 26 out of the total 27 countries within this category, only surpassing Ethiopia. The nation lags behind the "large countries" average on all three sub-parameters of HDI - health, education and income, with the gap widest in income and education. Countries with high tax to GDP have a sustainable growth of HDI, meaning countries with efficient tax system have high tax to GDP and HDI. Nigeria tax revenue contribution to her GDP is low and below others, (SSA, OECD and the world average). This therefore calls for drastic and renewed efforts to overhaul the tax system. The positive headway on this will lead to an improvement in the country's HDI and other economic development indices.

\section{Conclusion and recommendations Conclusion}

Taxation is one of the most reliable sources of revenue for national development. The importance of taxation in developing national economy is vital and taxation can be described as irreplaceable in terms of its contribution to economic development. This study assessed the effect of Tax administration system on economic development of Nigeria looking at the period of $2010-2019$. Nigeria tax system has been evolving, albeit with no synergised or cohesive strategic direction. Although the tax system has produced one of the lowest contributions to national revenue or GDP when compared with global trend, the impact of tax revenue on national economic growth could be significant as demonstrated by other nations like OECD countries, and SubSaharan African countries like South Africa with a tax to GDP of $26 \%$. Even though the country has recorded slight growth in nominal GDP, particularly before the advent of the Corona virus pandemic, the economic development of the nation has been crawling at an abysmally low level and even assuming a negative trend in some of the indices. This is evidenced from the latest ranking of HDI where Nigeria was ranked 161 out of 189 countries listed.

Findings from the study led to the conclusion that the tax system has significant effect on Nigerian economic development for the period under review. Although there appears to be no panacea for reformation of the Nigerian tax system, the country can take cue from the experiences of other emerging economies like Georgia and Rwanda as enunciated earlier. The thrust is to have targeted reforms aimed at enhancing the efficiency of the tax system and thereby significantly improve the tax income contribution to GDP and ultimately impact economic development. This will inevitably translate to the broadening of the tax base, creating a robust and sustainable income generation platform for the nation. 


\section{Recommendations}

There is need for government to clearly state the basic objectives of its tax system and the relationship between these objectives. This will give the tax administrators a sense of direction and educate the tax payers on the reasons to pay tax as at when due. Consequently, there is the need for the government to set clear strategic objectives for the tax system and also put in place a cohesive structure that coordinates and harmonise the entire tax structure in a versatile manner and responsive to the prevailing national and global trends and developments.

Other salient factors like IT utilization, education and awareness to tax payers are needed to boost tax system efficiency. An efficient tax administration system will produce increased and optimal revenue which will in turn significantly improve the economic development of the nation. In addition, government should organize intensive training for all tax officials so as to identify the loopholes in tax payment system and thereby entrench transparency and accountability. Government should improve on the use of IT and other global initiatives that have helped other nations in improving their tax revenue. Finally, government should ensure effective utilization of the income accrued taxation to provide the requisite infrastructure and expenditure that elevates economic development.

\section{References}

[1].Abata, M. A. (2017). The impact of tax revenue on Nigerian economy (Case of Federal Board of Inland

[2].Revenue). Journal of Policy and Development Studies Vol. 9, No. 1 November 2014 ISSN: 1579385Website: www.arabianjbmr.com/JPDS_index.php

[3].Adudu S. A \& Ojonye M. S., (2015). The impact of tax policy on economic growth in Nigeria. Retrieved from: https://www.iiste.org/Journals/index.php/JEDS/article/view/21913

[4].Agarwal P. (2019). Economic Development. Intelligent Economist Journal. Retrieved from: https://www.intelligenteconomist.com/economic-development/

[5].Aghion P. \& Howitt P. (1998). Endogenous economic growth theory. Retrieved from:

[6].https://mitpress.mit.edu/books/endogenous-growth-theory

[7].Brookings (2015). Are African countries rebasing GDP in 2014 finding evidence of-structural transformation?

[8].Retrieved from: https://www.google.com/search?q=Brookings+(2015).+Are-African-CountriesRebasingGDP-In-2014-Finding-Evidence-Of-Structural-Transformation

[9].Corporate Finance Institute, (2019). Economic growth theory. Retrieved from:

[10]. https://corporatefinanceinstitute.com/resources/knowledge/economics/endogenous-growth-theory/

[11]. Denver-South, (2018). What is Economic Development? Retrieved from: https://denver-south.com/whatiseconomic-development?/

[12]. Ehigiamusoe U., (2014)The Nexus between tax structure and economic growth in Nigeria: A prognosis. Article in Journal of Economic and Social Studies · January 2014 DOI: 10.14706/JECOSS11417

[13]. European Union, (2000). Economic growth in the European Union. Tourism and Management Studies International Conference Algarne Vol.3

[14]. Ewa U., Adesola W, \& Essien E (2020). Impact of tax revenue on economic development in Nigeria. International Business Research; Vol. 13, No. 6; ISSN 1913-9004 E-ISSN 1913-9012

[15]. FIRS, (2019). Retrieved from: https://www.firs.gov.ng/TaxLaws)

[16]. FIRS, (2020). Tax/Statistics Report. Retrieved from: https://www.firs.gov.ng/TaxLaws)

[17]. Ibanichuka, E. L., Ikebujo, O.S. \& Akani, F. N. (2016). A time series analysis of effect of tax revenue on economic development of Nigeria. International Journal of Innovative Finance and Economics Research, 4(3), 16-23.

[18]. ICAN, (2009). Retrieved From:

[19]. https://www.icanig.org/students/documents/PATHFINDER_MAY-2009-Professional.pdf.

[20]. Macek R. (2015). The impact of taxation on economic growth: Case study of OECD countries. Mayor Vihar Phase 1, Delhi. Management. Vol 6 No 2. Pp $128-136$.

[21]. Maiye O. \& Isiadinso (2019) Nigeria's unchanging tax to GDP ratio. Anderson. Retrieved from: https://www.mondaq.com/nigeria/tax-authorities/760270/nigeria39s-unchanging-tax-to-GDP-ratio

[22]. Nzotta, S.M. (2007). Tax evasion problems in Nigeria: A critique, The Nigerian Accountant, 40(2): 40-43.

[23]. OECD, (2018). Report to G-20 Finance Ministers and Central Bank Governors, Tax policies for inclusive growth in a changing world

[24]. OECD, (2020). Revenue Statistics in Africa 2020 - Nigeria. Retrieved from:

[25]. https://www.google.com/search?q=Revenue+Statistics+in+Africa+2020+\%E2\%94\%80+Nigeria

[26]. Ofoegbu, G. N., Akwu, D. O. \& Oliver, O. (2016). Empirical analysis of effect of tax revenue on economic development of Nigeria. International Journal of Asian Social Science, 6(10), 604-613.

[27]. Ogbonna G \& Odoemelam N., (2015). Impact of Taxation on Economic Development of

[28]. Nigeria 2000-2013

[29]. Ogbonna, G.N. \& Appah, E. (2016). Effect of Tax Administration and Revenue on Economic Growth in Nigeria. Research Journal of Finance and Accounting.ISSN 2222-1697 (Paper) ISSN 2222-2847 (Online).Vol.7, No.13, 2016

[30]. Okwara, C. C. \& Amori , O. M. (2014). Impact of tax revenue on economic growth in Nigeria. International Journal of Scientific Research in Social Sciences \& Management Studies | IJSRSSMS ISSN Print: 2579-101X| ISSN Online: 2579-1928| Vol. 2, No. 2

[31]. Pantamee A.A. \& Mansor M.B. (2016) A Modernize Tax Administration Model for Revenue Generation.

[32]. International Journal of Economics and Financial Issues, 2016, Sharhoodi S.M.M. (2010). Investigation of the effective factors in the efficiency of tax system 
[33]. Solow, R.M. Swan, T.W. (1956) Economic growth and capital accumulation. Economic Record, 32, $334-361$. Retrieve from:

[34]. https://doi.org/10.1111/j.1475-4932.1956.tb00434.x

[35]. Tosun, M.S. \& Abizadeh S. (2005): Economic growth and tax components: an analysis of tax changes in OECD. Journal of Applied Economics. Vol 37 pp 22251 - 2263.

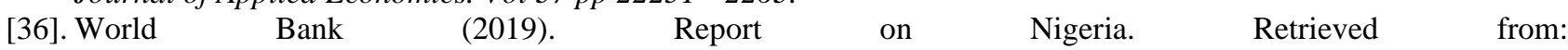
Https://Www.Worldbank.Org/En/Country/Nigeria/Overview

[37]. Yusuf, K. (2017). Africa turns to tax reform. Retrieved from: https://www.accaglobal.com/my/en/member/member/accounting- business /2017/01/ insights/africatax.html 